\title{
A rational approach to uninvestigated dyspepsia in primary care: review of the literature
}

\author{
N L A Arents, J C Thijs, J H Kleibeuker
}

Postgrad Med J 2002;78:707-716

In this paper the rationale and limitations of the four most important approach strategies to dyspepsia in primary care (empiric treatment, prompt endoscopy, "test-and-scope", and "test-and-treat") are analysed. It is concluded that in the absence of alarm symptoms, a "test-and-treat" approach is currently the most rational approach provided that three conditions are met: (1) a highly accurate test should be used, (2) the prevalence of Helicobacter pylori in the population should not be too low, and (3) an effective anti-H pylori regimen should be prescribed taking sufficient time to instruct and motivate the patient.

See end of article for authors' affiliations

Correspondence to: Dr J C Thijs, Bethesda Hospital, Dr G H

Amshoffweg 1, 7909 AA

Hoogeveen, The

Netherlands;

n.l.a.arents@mmb.azg.nl

Submitted 27 May 2002

Accepted

1 October 2002

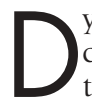

yspepsia is not a diagnosis, but merely a cluster of symptoms believed to be referable to the upper gastrointestinal tract. ${ }^{1-4}$ It is very common in the adult Western population with prevalence rates ranging from 19\% up to $41 \%$ in several epidemiological studies. ${ }^{5-17}$ Although most dyspeptics do not seek medical attention, half of them regularly use over the counter drugs. ${ }^{1012} 16$ About one out of every four subjects with dyspepsia consults his general practitioner, ${ }^{9} 10131618$ and these visits account for $1 \%-4 \%$ of all consultations in primary care. ${ }^{9}{ }^{12} 19$ Twenty five per cent of these patients are referred for further investigations (that is, endoscopy, ultrasonography, etc) or to a secondary care physician (about 10\%) but the majority of patients are managed empirically by their general practitioner. $^{91020-22}$ Altogether, dyspepsia is an cant clinical problem in primary care.

The objective of general practitioners when dealing with dyspeptic patients is to abolish or reduce symptoms, either by the detection and treatment of underlying disease or by symptomatic treatment or mere reassurance of the patient. Secondary objectives are the timely diagnosis of significant disease, avoidance of overtreatment, and containment of costs (box 1 ). The optimal approach to achieve these goals, however, is still a matter of discussion, even though several guidelines have been formulated. ${ }^{23-25}$ This current lack of agreement is related to several points, starting with the definition of dyspepsia. According to the recent Rome consensus the term dyspepsia refers to persistent or recurrent upper abdominal pain or discomfort, supposed to be referable to the upper gastrointestinal tract. ${ }^{26}$ The consensus meeting excluded patients with heartburn or acid regurgitation as the predominant important health issue and constitutes a signifi- symptom, as these symptoms were thought to be predictive of gastro-oesophageal reflux disease (GORD). ${ }^{27}{ }^{28}$ Nevertheless, many studies on dyspepsia used other definitions and some do include patients with predominant heartburn. ${ }^{9-11}{ }^{13} 16 \mathrm{Sec}-$ ondly, the optimal approach of the dyspeptic patient depends on the prevalences of the underlying causes of dyspepsia. These prevalences differ between various parts of the world. For example, in South East Asia, where gastric cancer is a common condition, ${ }^{29}$ the optimal approach is likely to be different from that in the Western world. ${ }^{30}$ Thirdly, the role of some conditions in causing dyspeptic symptoms is still debated. This is especially true for the relationship between Helicobacter pylori gastritis and dyspepsia without an endoscopically identifiable cause (functional dyspepsia). Finally, what is the most cost effective approach largely depends on the local availability and costs of medical provisions (especially endoscopy).

The primary care physician can choose between the following strategies when dealing with uninvestigated dyspepsia: (1) symptom guided empirical treatment, (2) direct referral for endoscopy, (3) non-invasive testing for $H$ pylori and subjecting the $H$ pylori positive patients to endoscopy ("test-and-scope"), and (4) non-invasive testing for $H$ pylori and treatment of the infection in $H$ pylori positive patients ("test-and-treat"). The aim of this review is to evaluate the rationale behind each strategy and to weigh the available clinical evidence. It focuses on dyspepsia as encountered in primary care and the situation in the Western world. It does not discuss the approach of the patients with mild symptoms of short duration, which usually can be managed by reassurance and simple lifestyle advice. Nor does it consider the approach of patients with heartburn or acid regurgitation as the only or predominant symptom. It is recognised, however, that heartburn is frequently part of the dyspeptic syndrome. ${ }^{26}$ Finally, patients with "alarm" symptoms (box 2) and patients using non-steroidal anti-inflammatory drugs (NSAIDs) are not subjects of this review. Patients with alarm symptoms should be subjected to endoscopy without delay. In patients using NSAIDs, this drug should be discontinued if at all possible before considering further steps.

Abbreviations: GORD, gastro-oesophageal reflux disease; NSAID, non-steroidal anti-inflammatory drug 
Box 1: Objectives in dealing with the dyspeptic patient in primary care

- Abolishment or reduction of symptoms.

- Timely diagnosis of significant disease.

- Avoidance of over-treatment.

- Containment of medical and non-medical costs.

Box 2: Sinister symptoms in the dyspeptic patient that necessitate endoscopy

- Unintentional weight loss.

- Iron deficiency anaemia.

- Gastrointestinal bleeding

- Dysphagia.

- Odynophagia.

- Previous gastric surgery.

- Persistent vomiting.

- Epigastric mass.

\section{DIFFERENTIAL DIAGNOSIS IN UNINVESTIGATED DYSPEPSIA}

Dyspepsia can be ascribed to several conditions. Only a few studies have examined their relative prevalences in a primary care population. In three studies all patients consulting their general practitioner for dyspeptic symptoms were referred for endoscopy. Reflux oesophagitis was found in $6 \%-24 \%$, peptic ulcer disease in $13 \%-16 \%$, malignant disease in $1 \%-2 \%$, and in more than $60 \%$ of the patients no abnormalities were found at endoscopy, ${ }^{31-33}$ the latter patients being usually diagnosed as having functional dyspepsia. More data are available from studies evaluating "open access endoscopy". In "open access endoscopy" the general practitioner directly refers the patients for upper gastrointestinal endoscopy without prior evaluation by a specialist. Data from these studies should, however, be considered with caution. The patients represent a selected population, as no more than $25 \%$ of the patients in primary care are referred for further investigations. ${ }^{910}$ In these studies oesophagitis was diagnosed in $2 \%-31 \%$, peptic ulcer disease in $13 \%-28 \%$, a malignancy in $0.2 \%-4.0 \%$, and endoscopy revealed no visible disease in $35 \%-89 \%$. In table 1 the data from the three primary care studies and the "open access endoscopy" studies with over 400 participating patients each are summarised. ${ }^{31-50}$ Considering these data, it is noteworthy that the ranges of frequencies of the various endoscopic diagnoses in the studies evaluating "open access endoscopy" are very much alike those in the primary care studies. This suggests that clinical judgment does not adequately select patients at higher risk for underlying pathology, which is in line with other studies showing that it is impossible to predict endoscopic lesions in dyspeptic patients only from the clinical presentation. ${ }^{16455152}$ It is recognised, however, that in daily practice clinical judgment is not the only consideration to refer a patient for endoscopy, and other reasons, like a patient's fear of cancer, may be involved. It is also noteworthy that the prevalences of endoscopic diagnoses vary considerably among the studies. This is probably explained by differences in inclusion criteria and by geographic differences, but prevalences are also changing. Several studies have shown that during the last decades the prevalences of GORD and adenocarcinoma of the oesophagus and cardia have been increasing rapidly in the Western world, together with decreasing prevalences of peptic ulcer disease and distal gastric cancer. ${ }^{53-55}$ The decreasing prevalence of $H$ pylori infection is generally considered to contribute to these epidemiological changes. ${ }^{56}$ Considering these varying and changing prevalences of underlying conditions in dyspepsia, it is obvious that the optimal approach of the dyspeptic patient may be different between the various geographic regions and may also change with time.

\section{ROLE OF H PYLORI IN DYSPEPSIA}

In the years after the first description of $H$ pylori by Warren and Marshall in $1983^{57}$ it has become clear that this Gram negative curved bacterium plays a major part in several conditions of the upper gastrointestinal tract. There is ample evidence showing a causal relationship between $H$ pylori infection and peptic ulcer disease. When patients using NSAIDs are excluded, the large majority of patients with peptic ulcer disease carry the infection ${ }^{58}$ and eradication of $H$ pylori heals the disease ${ }^{59-66}$ and prevents its recurrence. ${ }^{61-64}{ }^{66-69}$ Moreover, $H$ pylori gastritis is the most important risk factor for the subsequent development of peptic ulcer disease, ${ }^{7071}$ a risk that has been estimated to be about $10 \%$ in a lifetime. ${ }^{72}{ }^{73}$ On the other hand, several recent studies show that not all peptic ulcer disease is caused by $H$ pylori, even after exclusion of patients using NSAIDs. ${ }^{74-78}$ The decreasing prevalence of $H$ pylori in the Western world is likely to cause a relative increase in the proportion of these "idiopathic" peptic ulcers. ${ }^{76} 79$

In addition to the causal relation with peptic ulcer disease, it has been shown that there is also a strong association between $H$ pylori gastritis and the occurrence of gastric cancer $^{80-89}$ and the International Agency for Research on Cancer has classified $H$ pylori as a class I risk factor for gastric cancer. ${ }^{90}$ Moreover, gastric MALT lymphoma (mucosa associated lymphoid tissue lymphoma $)^{91-93}$ and Ménétrier's disease of the stomach have been associated with $H$ pylori ${ }^{94-96}$ These conditions, however, are rare, and therefore this association will not be a major factor influencing decision making in the dyspeptic patient.

The relationship between $H$ pylori and functional dyspepsia has been debated for a long time and is still not entirely clarified..$^{97} 98$ Several studies have suggested a higher prevalence of $H$ pylori in functional dyspepsia, but others came to dissimilar conclusions. ${ }^{99} 100$ Decisive evidence could be expected from studies evaluating the effect of $H$ pylori eradication on symptoms in functional dyspepsia. Early studies were flawed by methodological problems, ${ }^{101}{ }^{102}$ but recently four large well conducted randomised placebo controlled clinical trials with a follow up period of 12 months have been published as full papers. ${ }^{103-106}$ The results, however, are contradictory (table 2). A recent meta-analysis included these studies as well as five other studies ${ }^{107-111}$ and suggested that there is a small but significant benefit of about $10 \%$ of $\mathrm{H}$ pylori eradication over placebo. ${ }^{112}$ Another meta-analysis, however, included other studies ${ }^{109}$ 113-117 apart from the ones listed in table 2 and did not show any benefit. ${ }^{118}$

$H$ pylori infection does not seem to be a causal factor in the pathogenesis of GORD. ${ }^{119-121}$ Epidemiological data even suggest that the infection protects against this condition. While the prevalence of $H$ pylori gastritis is declining in the Western world, GORD and Barrett's carcinoma are becoming more common..$^{53}{ }^{122}{ }^{123}$ Moreover, some studies suggest that eradication of $H$ pylori can induce GORD, ${ }^{124}{ }^{125}$ although this has not been confirmed by others. ${ }^{126-128}$

\section{IMMEDIATE ENDOSCOPY OR SYMPTOM GUIDED EMPIRICAL TREATMENT}

Endoscopy is the most appropriate investigation to detect pathological lesions in the upper alimentary tract as well as the presence of $H$ pylori. ${ }^{129}{ }^{130}$ Immediate endoscopy in patients with dyspepsia results in a definite diagnosis from the outset and ensures that the patient receives the most appropriate treatment. It is evident that in most patients with dyspepsia no underlying disease can be identified. Several studies, however, have shown that even then an endoscopy may have its merits. A negative endoscopy may have a significant reassuring effect and may result in a decreased use of medication and 
Table 1 Prevalences of endoscopically encountered diseases in dyspeptic patients

\begin{tabular}{|c|c|c|c|c|c|}
\hline & No & $\begin{array}{l}\text { Reflux } \\
\text { oesophagitis (\%) }\end{array}$ & $\begin{array}{l}\text { Peptic ulcer } \\
\text { disease (\%) }\end{array}$ & $\begin{array}{l}\text { Malignancy } \\
(\%)\end{array}$ & $\begin{array}{l}\text { Functional } \\
\text { dyspepsia (\%) }\end{array}$ \\
\hline \multicolumn{6}{|c|}{ Unselected primary care patients } \\
\hline Heikinnen et $a^{\beta 1}$ * & 400 & 15 & 13 & 2.3 & 70 \\
\hline Kagevi et $a^{\beta 2 *}$ & 172 & 6 & 13 & 1.2 & 79 \\
\hline Hansen et $a^{\beta 3}$ & 612 & 24 & 16 & 0.7 & 59 \\
\hline Range & & $6-24$ & $13-16$ & $0.7-2.3$ & $59-79$ \\
\hline Weighted mean & & 18 & 15 & 1.3 & 66 \\
\hline \multicolumn{6}{|c|}{ Open acces endoscopy studies with $>400$ patients } \\
\hline Ayoola et $a^{\beta 4 *}$ & 10112 & 11 & 17 & 1.5 & 70 \\
\hline Hungin et $a^{\beta 5}$ & 6744 & 17 & 15 & 0.6 & 67 \\
\hline Hallisey et $a^{\beta \sigma}$ & 2659 & 19 & 16 & 2.7 & 62 \\
\hline Fedail et $a^{\beta 7}$ & 2500 & 8 & 18 & 2.2 & 71 \\
\hline Mansi et $a^{\beta 8}$ & 2086 & 5 & 13 & 1.5 & 81 \\
\hline Holdstock et $a^{\beta 9}$ & 1805 & 9 & 14 & 2.0 & 75 \\
\hline Fiosne et $\left.a\right|^{40 *}$ & 1275 & 10 & 23 & 4.0 & 62 \\
\hline Capurso et $a^{41}$ & 1153 & 3 & 8 & 0.6 & 89 \\
\hline Stanghellini et a ${ }^{42}$ & 1057 & 9 & 21 & 0.6 & 69 \\
\hline Davenport et a ${ }^{43}$ & 1041 & NA & 24 & 2.6 & NA \\
\hline Nyren et a ${ }^{44}$ & 972 & 3 & 23 & 0.3 & 74 \\
\hline Gear et $a^{45}$ & 968 & 5 & 17 & 2.3 & 76 \\
\hline Johannessen et $a^{146 *}$ & 930 & 15 & 17 & 1.0 & 67 \\
\hline Bytzer et $a^{14^{7}}$ & 878 & 2 & 15 & 1.4 & 82 \\
\hline Talley et a ${ }^{48}$ & 820 & 14 & 23 & 3.4 & 60 \\
\hline Williams et a ${ }^{49}$ & 686 & 14 & 28 & 2.5 & 56 \\
\hline Saunders et a ${ }^{50 *}$ & 559 & 31 & 23 & 0.2 & 46 \\
\hline Range (\%) & & $2-31$ & $13-28$ & $0.2-4.0$ & $35-89$ \\
\hline Weighted mean $(\%)$ & & 12 & 17 & 1.6 & 70 \\
\hline \multicolumn{6}{|c|}{$\begin{array}{l}\text { NA, data not available. } \\
\text { *In these studies more than one diagnosis was allowed in a single patient. Therefore, as functional dyspepsia } \\
\text { was defined as the absence of either reflux oesophagitis, peptic ulcer disease or malignancy, this may have } \\
\text { led to an underestimation of the percentage of patients with functional dyspepsia (within a total of } 100 \% \text { ). }\end{array}$} \\
\hline
\end{tabular}

in fewer medical consultations. ${ }^{131-133}$ Investigating all dyspeptic patients by endoscopy, however, is not feasible in view of the high incidence of dyspepsia and the limited availability of endoscopic facilities. Therefore, alternative approaches have been suggested.

Many dyspeptic patients consult their general practitioner mainly because of fear of possible serious disease and sometimes mere reassurance may be sufficient. ${ }^{131846134}$ If the symptoms do not abolish spontaneously, it has been proposed to prescribe a trial of treatment, reserving endoscopy for those patients who do not respond or whose symptoms recur after stopping treatment. ${ }^{20-22}{ }^{135}$ This strategy has been promoted by several organisations of both primary and secondary care physicians. ${ }^{25} 49129136$ The choice of the drug may be dictated by the predominant symptom ${ }^{2}$ but treatment most often consists of an acid suppressing drug given during a fixed period. $\mathrm{H}_{2}$-receptor blocking agents are used predominantly, although they are being gradually replaced by the more powerful proton pump inhibiting drugs. Acid suppression is effective in GORD and peptic ulcer disease and a few studies have shown some efficacy in functional dyspepsia. ${ }^{137-140}$ Besides acid suppressive

Table 2 Effect of $H$ pylori eradication on symptom improvement in patients with functional dyspepsia: results of double blind placebo controlled studies with one year follow up published as full papers

\begin{tabular}{llll}
\hline & No & $\begin{array}{l}\text { Anti-H pylori treatment } \\
\text { (\% symptom } \\
\text { improvement) }\end{array}$ & $\begin{array}{l}\text { Placebo } \\
\text { (\% symptom } \\
\text { improvement) }\end{array}$ \\
\hline Blum et al ${ }^{106}$ & 328 & 27.4 & 20.7 \\
McColl et $a l^{105}$ & 318 & 21 & $7^{*}$ \\
Talley et $a l^{104}$ & 275 & 24.1 & 21.8 \\
Talley et $a l^{103}$ & 337 & 46 & 50 \\
\hline${ }^{*} \mathrm{p}=0.03$ & & &
\end{tabular}

drugs, prokinetics, especially cisapride, have been advocated for the empirical treatment of uninvestigated dyspepsia. This drug is shown to be of benefit in GORD ${ }^{141-152}$ and functional dyspepsia, ${ }^{153-160}$ and may have some efficacy in peptic ulcer disease. ${ }^{161-164}$ Recently, however, serious cardiac side effects of cisapride were reported and, for that reason, the drug has been withdrawn from the US market. ${ }^{165}$

\section{SELECTION FOR ENDOSCOPY BY NON-INVASIVE TESTING FOR H PYLORI: THE "TEST-AND- SCOPE" AND "TEST-AND-TREAT" STRATEGIES}

The incorporation of the $H$ pylori concept in the approach of uninvestigated dyspepsia has led to the development of two major strategies: "test-and-scope" and "test-and-treat".

The "test-and-scope" strategy was first suggested by Sobala et al in $1991{ }^{166}$ They reasoned that dyspeptic patients under the age of 45 without alarm symptoms or NSAID use and testing negative for $H$ pylori by non-invasive means have a very low probability for serious underlying disease. Therefore, they postulated that these patients could safely be treated empirically, without the need for an endoscopy. When this strategy was tested retrospectively in a group of 293 patients referred for endoscopy, they found that the total number of endoscopies performed would have been reduced by $25 \%$ in all age groups and by $48 \%$ in the age group below 45 years, without missing any peptic ulcer or malignancy. Other retrospective studies showed comparable results with a reduction in the number of endoscopies between $11 \%$ and $35 \%$ when all patients referred for endoscopy were considered, but at the cost of missing up to $2 \%$ of the peptic ulcers. ${ }^{167-175}$ Patel et al were the first to evaluate this strategy prospectively in 183 consecutive patients. ${ }^{176}$ Seventy patients below the age of 45 without sinister symptoms or NSAID use and testing $H$ pylori negative by serology were referred back to their general practitioner for symptomatic treatment without an endoscopy 
Box 3: Factors with significant impact on the cost effectiveness of the various approaches in patients with dyspepsia

- Cost of endoscopy

- Cost of treatment.

- Cost of physician visit.

- Prevalence of $\mathrm{H}$ pylori in the dyspeptic population.

- Prevalence of peptic ulcer disease in $H$ pylori positive patients.

- Prevalence of underlying diseases in dyspepsia.

- Benefit of $H$ pylori eradication in patients with functional dyspepsia.

- Recurrence of dyspeptic symptoms in patients with (functional) dyspepsia after treatment.

performed. Only three of these patients eventually underwent endoscopy, resulting in an overall reduction in the number of endoscopies by $37 \%$. Moreover, endoscopy did not seem to influence subsequent symptom severity, quality of life, and number of days lost from work when these non-endoscoped patients were compared with a historic control group of $H$ pylori negative endoscoped subjects. The number of physician visits and medication use were even less in these nonendoscoped patients. This is in accordance with the study of Asante et al, who showed that endoscopy in seronegative patients does not influence quality of life, number of visits to the general practitioner, or number of days lost from work. ${ }^{177}$

A further reduction in the number of endoscopies could possibly be reached if $H$ pylori positive dyspeptic patients were not subjected to endoscopy, but received immediate anti- $H$ pylori treatment: the "test-and-treat" strategy. In this way, patients with $H$ pylori related peptic ulcer disease would be treated adequately without the need for an endoscopy. If the symptoms persisted, the patient could still be referred for endoscopy.

\section{STUDIES COMPARING THE VARIOUS STRATEGIES}

In several studies the various strategies to approach the dyspeptic patient were compared by computer assisted decision analysis. ${ }^{178-185}$ Decision analysis is a quantitative method for estimating the outcome, both clinical and financial, of alternative management strategies. In such an analysis calculations are based on data from the literature and on estimates by expert opinion. Data in the model are often uncertain but recalculation of the outcome after varying a single assumption over a reasonable range can be used to show to what extent different parameters influence the conclusions. In that way these studies have identified factors, summarised in box 3, that have a significant impact on the cost effectiveness of any approach of dyspepsia. Most studies concluded that a non-invasive approach, especially by a "testand-treat" strategy, is likely to be the most cost effective, ${ }^{178}{ }^{181-185}$ although this conclusion was heavily influenced by the costs of endoscopy. ${ }^{179}$ In these decision analytic studies, however, not all variables were incorporated in the model and, some aspects with a possible impact on the outcome of a strategy were not studied. Such aspects include a positive family history (peptic ulcer disease, cancer), the possible reassuring effect of a negative endoscopy, and the significance of detecting Barrett's oesophagus, to name a few. Therefore, such mathematical studies cannot replace prospective clinical trials.

Just a few randomised trials have evaluated the various approaches of the dyspeptic patient in a clinical setting. ${ }^{131}{ }^{186-190}$ Most of them compared a non-invasive approach, either the "test-and-treat" strategy or empirical acid suppressive treatment, with prompt endoscopy. The "test-andtreat" strategy was evaluated in a limited number of studies. ${ }^{186-188191}$ Heaney et al randomised $H$ pylori positive patients as determined by the ${ }^{13} \mathrm{C}$-urea breath test to either anti-H pylori treatment or prompt endoscopy. ${ }^{186}$ In the endoscopy group only the patients with peptic ulcer disease received anti-H pylori treatment. At one year follow up, only $27 \%$ of the patients who were not endoscoped initially had undergone endoscopy. The dyspepsia scores had improved significantly more in the non-endoscoped patients than in those subjected to endoscopy. Jones et al compared the "test-andtreat" strategy with standard clinical care in primary care. ${ }^{187}$ In standard clinical care, only patients with proved peptic ulcer disease received anti- $H$ pylori treatment. It was shown that during a follow up of one year, only $12 \%$ of the patients in the "test-and-treat" group eventually underwent endoscopy, compared with patients receiving standard clinical care. Clinical outcome was comparable in both groups, but medical costs in the "test-and-treat" group were only about half of that in the control group. Lassen et al compared the "test-and-treat" strategy using the ${ }^{13} \mathrm{C}$-urea breath test with prompt endoscopy. ${ }^{188}$ Again, in the endoscopy arm, only the patients with peptic ulcer disease received anti- $H$ pylori treatment. At the end, $40 \%$ of the patients in the "test-and-treat" group had been referred for endoscopy. Symptom resolution, changes in quality of life, the use of resources (medication, visits to outpatient clinics, days in hospital, visits to general practitioner), and the number of sick leave days were comparable in both study groups. Patients in the endoscopy group, however, were more satisfied with the treatment and were more often prescribed proton pump inhibitors. It was concluded that the "test-and-treat" strategy is as efficient and safe as prompt endoscopy. Finally, Arents et al compared the "test-and-treat" strategy using $H$ pylori serology with prompt endoscopy. ${ }^{191}$ In contrast to other studies, all $H$ pylori positive patients received anti-H pylori treatment in both study arms. At one year of follow up, $40 \%$ of the patients in the "test-and-treat" group had been referred for endoscopy. Symptom resolution, improvement in quality of life, and patient satisfaction were comparable in both study groups.

The most important study comparing acid suppression to prompt endoscopy was performed by Bytzer et al. ${ }^{131}$ In that study, patients were randomised to prompt endoscopy or to a trial of empirical treatment with $\mathrm{H}_{2}$-receptor blocking agents. Prompt endoscopy proved to be more cost effective and to cause more patient satisfaction than empirical treatment with an $\mathrm{H}_{2}$-receptor blocking agents. Laheij et al compared prompt endoscopy with an approach in which patients initially received empirical treatment with omeprazole, followed by a "test-and-treat" strategy if symptoms persisted. ${ }^{189}$ After one year of follow up, $31 \%$ of the patients in the group receiving empirical treatment had been referred for endoscopy. Clinical outcome was the same in both groups, but medical costs were lower in the group at first subjected to empirical treatment. Finally, in one study, all four different strategies were compared: initial treatment with acid suppression, "test-andtreat", "test-and-scope", and immediate endoscopy. ${ }^{190}$ In that study, prompt endoscopy was initially the most expensive approach, but after a one year follow up period it became the most cost effective one as subsequent costs were reduced.

Like the decision analytic studies, these clinical studies also have their limitations. They were performed in a specific setting in which the factors, listed in box 3, all have their significant influence on the outcome. These factors may have a diverse impact in different regions or clinical settings. For instance, all studies, except the study by Arents et al, were performed in a secondary care setting and the results may not be applicable for the dyspeptic patient visiting his primary care physician. Moreover, all studies used a specific treatment protocol. For example, in the two trials comparing a "test-andtreat" strategy with prompt endoscopy, all patients testing positive for $H$ pylori in the "test-and-treat" group received anti-H pylori treatment whereas $H$ pylori positive patients in 
the endoscopy group only received such treatment if they had endoscopic evidence of peptic ulcer disease denying functional dyspepsia patients any possible benefit of anti- $H$ pylori treatment. Such a study design may have biased the results.

\section{RATIONALE AND LIMITATIONS OF THE VARIOUS APPROACHES OF THE DYSPEPTIC PATIENT}

The optimal approach to the dyspeptic patient in primary care is the one that best serves the objectives listed in box 1 . Frequently, none of the aforementioned strategies will positively serve all these objectives and in clinical practice none of the strategies is always clearly superior to the others. What is the most cost effective strategy is determined by the factors enumerated in box 3 and the significance and impact of most of these factors may vary considerably between different regions of the world. Even within a single region, however, it is not likely that a single strategy is the best one in every patient. Sometimes a different approach should be chosen as dictated by the characteristics of the individual patient (age, family history, comorbidity, fear of cancer, etc). Therefore, it is the authors' view that, in order to be able to treat the dyspeptic patient in the most cost effective way, the primary care physician should be aware of the factors listed in box 3 and understand the rationale and limitations of the various approaches of uninvestigated dyspepsia.

If one chooses to prescribe empirical treatment with an acid suppressive agent, what can be expected? It is evident that acid suppressive therapy will be beneficial in patients with peptic ulcer disease and GORD. ${ }^{192-197}$ In functional dyspepsia the benefit of acid suppressive drugs is less clear. Studies examining the efficacy of acid suppressive agents in this condition are difficult to evaluate, ${ }^{153^{157} 198-203}$ but about half of the studies examining $\mathrm{H}_{2}$-receptor blocking agents show a modest positive effect. Only a few randomised placebo controlled trials studied the efficacy of proton pump inhibitors in functional dyspepsia and showed a benefit of about $10 \%$ over placebo. ${ }^{137-140} 204$ Taken together with the well known large placebo effect of any drug in functional dyspepsia, ${ }^{153}{ }^{157}$ these data explain that a trial of treatment with an acid suppressive agent reduces symptoms in a fair number of patients with uninvestigated dyspepsia. Nevertheless, several objections can be made to such an approach. The benefit of an attempt to treat the patient empirically depends on the number of patients becoming permanently symptom-free afterwards or at least for a long period. Unfortunately, in patients with peptic ulcer disease and GORD, symptoms usually recur after stopping the treatment. ${ }^{61} 193205206$ It is very likely that the same can be said about many patients with functional dyspepsia, as this is also often a chronic condition with the majority of the patients still experiencing symptoms after one year. ${ }^{75}{ }^{207-209}$ Therefore, it can be anticipated that, unless one is willing to continue acid suppression without a definite diagnosis, a trial with such medication just postpones endoscopy in most patients. This assumption is supported by the study of Bytzer et al who showed that $67 \%$ of dyspeptic patients who received empirical treatment with $\mathrm{H}_{2}$-receptor blocking agents underwent endoscopy within a year. ${ }^{131}$ The second objection that can be made against this approach is a practical one. If endoscopy is performed after all, signs of peptic ulcer disease or GORD may be obscured if the medication has not been withdrawn for a sufficiently long period before endoscopy as commonly occurs in clinical practice. A trial with a prokinetic drug (cisapride) will be of benefit in patients with GORD and probably in some with peptic ulcer disease and functional dyspepsia and will also have a considerable placebo effect in patients with functional dyspepsia. ${ }^{153}{ }^{157}$ Therefore, it can be anticipated that, like acid suppression, a trial of such treatment will have a favourable response in a fair number of patients. Most drawbacks mentioned above for acid suppression, however, are also pertinent for this class of drugs, although prokinetic agents are probably less likely to obscure endoscopic signs of GORD and peptic ulcer disease. The recently described cardiac side effects of cisapride will now limit its use.

What about continuing treatment without a definite diagnosis? Although this is an option, several objections can be made to such an approach. First, patients with peptic ulcer disease will be effectively treated, but a far more cost effective treatment (H pylori eradication) is to be preferred. ${ }^{210}$ Second, if patients with GORD, who are likely to respond well to potent acid suppression, are not subjected to endoscopy, Barrett's metaplasia will not be detected. This condition occurs in about $10 \%-15 \%$ of all patients with GORD, ${ }^{211-213}$ and is associated with an increased risk for oesophageal cancer, ${ }^{214-216}$ although it was recently suggested that this relative risk has been exaggerated. ${ }^{217}$ Recent studies have indeed confirmed the latter. ${ }^{218} 219$ Whether or not failure to diagnose Barrett's oesophagus is significant depends on one's view on the necessity of endoscopic surveillance of these patients. This is still an unsettled issue. ${ }^{214} 215216220-226$ Finally, it has been argued that empirical treatment with acid suppressive agents may lead to a significant delay in diagnosing malignant disease. ${ }^{227}$ In the Western world, however, this contention does not seem to hold as gastrointestinal malignancy is extremely rare in dyspeptic patients below $45-50$ years if alarm symptoms are not present. ${ }^{228-230}$

If one chooses to test for $H$ pylori one should first have knowledge of the reliability of the test results (its positive and negative predictive value). This is not only dependent on the characteristics of the test (sensitivity and specificity) but also on the prevalence of the infection in the population. For instance, as the prevalence of $H$ pylori infection is decreasing in the younger age group, the likelihood of a false positive test in this age group increases. This may be acceptable if a "test-and-scope" strategy is followed as the test can be confirmed by one or more biopsy based methods, but it is certainly not acceptable if one follows a "test-and-treat" strategy. In that case, only highly accurate tests (with very high specificity) are acceptable and serology will soon not be suitable anymore. Urea breath tests ${ }^{231} 232$ and stool antigen tests ${ }^{233-235}$ may be valuable alternatives.

Screening for $H$ pylori will provide one of two possibilities: a positive test result or a negative test result. A negative test result leads to the same approach in both the "test-andscope" and "test-and-treat" strategies. In such a patient peptic ulcer disease is highly unlikely, leaving functional dyspepsia and GORD as the most likely diagnoses. In the absence of alarm symptoms malignancies are extremely rare under the age of 50. ${ }^{228-230}$ Most patients can, therefore, safely be treated blindly with acid suppression. Endoscopy will not change the management in most of these patients. ${ }^{177}$

In case of a positive test result the "test-and-scope" strategy will detect most patients with peptic ulcer disease. Anti- $H$ pylori treatment can be limited to these patients as the benefit of such a treatment is only shown decisively in peptic ulcer disease. ${ }^{236}$ Treatment can be guided by susceptibility testing based on $H$ pylori culture. In the "test-and-treat" strategy, however, all $H$ pylori positive patients receive anti- $H$ pylori treatment. This approach will be beneficial in most patients with peptic ulcer disease and possibly a few patients with functional dyspepsia, but in the large majority of patients there will be no short term benefit. Nevertheless, two additional arguments support the eradication of $H$ pylori in all patients with uninvestigated dyspepsia. First, in contrast to all other therapeutic options, anti-H pylori treatment only takes one to two weeks and, if successful, eliminates a potential cause of dyspepsia for lifetime, as reinfection is rare in the Western world..$^{69}{ }^{237-242}$ Second, it may have a positive effect by preventing future disease, especially peptic ulcer disease. ${ }^{71-73}$ Whether gastric cancer is prevented by eradication of $H$ pylori is still highly uncertain, ${ }^{243}$ but some have advocated prophylactic anti-H pylori treatment for patients on long term acid suppressive therapy as these patients may be at increased risk of 
Box 4: Arguments for and against $H$ pylori treatment in uninvestigated dyspepsia

For

- A single short term treatment, with lifelong effects when beneficial.

- Prevents future disease.

Against

- No benefit in most patients.

- Exposes patients to side effects.

- Induces antibiotic resistance (H pylori and other gastrointestinal bacteria).

- Possibly induces GORD after H pylori eradication.

developing gastric cancer. ${ }^{24-246}$ This issue is still debated ${ }^{247} 248$ but it may support $H$ pylori eradication in dyspeptic patients.

On the other hand, several arguments have been cited against treatment of the infection in all patients with uninvestigated dyspepsia in whom $H$ pylori is detected. First of all, it will not diminish symptoms in the large majority of patients and just expose them to the side effects of the anti- $H$ pylori regimen, ${ }^{249-253}$ even though these are usually mild and in a trial setting form a reason to discontinue treatment in less than $5 \%$ of all patients. ${ }^{250-254}$ Second, treating $H$ pylori infection in all these patients may induce antibiotic resistance. To what extent this occurs in clinical practice is not known. Antibiotic resistance in $H$ pylori is indeed a major problem ${ }^{254-258}$ and its prevalence seems to be increasing. ${ }^{259}{ }^{260}$ Whether this increase is caused by anti- $H$ pylori treatment or by the prescription of antibiotics for other indications, however, is not known. As the current anti- $H$ pylori regimens are so effective, with eradication rates of $>95 \%$ in susceptible strains, ${ }^{255}$ induction of resistance should be a rare event, as long as the regimen is properly prescribed and time is taken to instruct and motivate the patient. ${ }^{261}$ Third, eradication of $H$ pylori may induce other diseases, especially GORD, ${ }^{124}{ }^{125}{ }^{262}$ but this does not seem to be a clinically significant problem in the majority of patients. ${ }^{110}{ }^{263}$ Considering all these arguments favouring and renouncing $H$ pylori treatment in uninvestigated dyspepsia (box 4), it is the authors' view that the weight of the evidence favours treatment of the infection when it is diagnosed.

\section{CONCLUSIONS AND RECOMMENDATIONS}

It is unlikely that a single strategy will be applicable in all dyspeptic patients in primary care. Nevertheless, in our view, the "test-and-treat" strategy is currently a rational way to deal with many patients with uncomplicated dyspepsia, provided that the following conditions are met. First, the positive predictive value of the test should be adequate. Therefore, an accurate test should be used and the prevalence of the infection should be monitored. Second, an effective anti-H pylori treatment regimen should be used and time should be taken to instruct the patient in order to improve compliance. If the prevalence of $H$ pylori gets low, as is the case in the younger age group in Western countries, the "test-and-treat" strategy becomes less suitable. "Test-and-scope" becomes more appropriate as the positive non-invasive $H$ pylori test can be confirmed by two or more biopsy based tests. In our view, if the infection is confirmed, it should be treated even if no peptic ulcer disease is detected as such an approach may prevent future diagnostic dilemmas and possibly future disease. In both strategies all patients testing negative for $H$ pylori can safely be treated with acid suppression (or prokinetics if symptomatology suggests a motility disorder). If this treatment is successful, the medication should gradually be stopped if possible. If this approach fails and the patient remains symptomatic endoscopy should be considered mainly to reassure the patient, as it is unlikely to reveal underlying disease or change treatment. If the prevalence of $H$ pylori gets very low, as is likely to be the case in the future in Western societies, non-invasive testing for the micro-organism is probably not appropriate any more. In that situation empirical treatment may be the way to proceed, even though it may just postpone endoscopy in some patients. Acid suppressive drugs, especially proton pump inhibitors, are then the drugs of choice. Prokinetics may become an alternative but cisapride has recently been withdrawn from the market and other comparably effective prokinetic drugs, both in patients with functional dyspepsia and GORD, are not yet available. In some patients, however, the approach should be individualised as dictated by their personal history. Any alarm symptom should urge for an immediate endoscopy. A strong family history for peptic ulcer disease may be a persuasive argument in favour of a "test-and-treat" approach even if the prevalence of $H$ pylori is low. If fear of cancer is deep rooted early endoscopy should be considered. Therefore, the taking of an adequate medical history remains the mainstay of the approach of every patient. This holds no less for the dyspeptic patient in primary care.

\section{Authors' affiliations}

N L A Arents, Regional Public Health Laboratory, Groningen/Drenthe J C Thijs, Department of Gastroenterology, Bethesda Hospital, Hoogeveen

J H Kleibeuker, Department of Gastroenterology, University Hospital, Groningen, The Netherlands

\section{REFERENCES}

Crean GP, Card WI, Beatti AD, et al. Ulcer-like dyspepsia. Scand J Gastroenterol 1982;17(suppl 79):9-15.

2 Colin-Jones DG. Management of dyspepsia: report of a working party. Lancet 1988:i:576-9.

3 Barbara L, Camilleri M, Corinaldesi R, et al. Definition and investigation of dyspepsia. Dig Dis Sci 1989;34:1271-6.

4 Heading RC. Definitions of dyspepsia. Scand J Gastroenterol 1991;26(suppl 182): 1-6

5 Doll R, Jones AF, Bucjatzsch MM. Occupational factors in the aetiology of gastric and duodenal ulcers, with an estimate of their incidence in the general population. Medical Research Council Reports Series 1951:276:1-9.

1951;276: 1-9.
6 Tibblin G. Ulcusfrekvens bland 50-ariga man. Lakartidningen 1966;63:4825-9.

7 Weir RD, Backett EM. Studies of the epidemiology of peptic ulcer in a rural community: prevalence and natural history of dyspepsia and peptic urer. Gut 1968.9.75-83.

8 Johnsen R, Straume B, Forde OH. Peptic ulcer disease and non-ulcer dyspepsia-a disease and a disorder. Scand J Prim Health Care 1988;6:239-43.

9 Jones R, Lydeard S. Prevalence of symptoms of dyspepsia in the community. BMU 1989;298:30-32.

10 Jones RH, Lydread SE, Hobbs FDR, et al. Dyspepsia in England and Scotland. Gut 1990:31:401-5.

11 Bernersen B, Johnsen R, Straume B, et al. Towards a true prevalence of peptic ulcer: the Sorreisa gastrointestinal disorder study. Gut 1990;31:989-92

12 Knill-Jones RP. Geographical differences in the prevalence of dyspepsia. Scand J Gastroenterol 1991;26(suppl 182):17-24.

13 Talley NJ, Zinsmeister AR, Schleck CD, et al. Dyspepsia and dyspepsia subgroups: a population-based study. Gastroenterology 1992;102:1259-68.

14 Agreus L, Svardsudd K, Nyren O, et al. The epidemiology of abdominal symptoms: prevalence and demographic characteristics in a Swedish adult population. Scand J Gastroenterol 1994;29:102-9.

15 Kay L, Jorgensen T. Epidemiology of upper dyspepsia in a random population. Prevalence, incidence, natural history, and risk factors. Scand J Gastroenterol 1994;29:2-6.

16 Penston JG, Pounder RE. A survey of dyspepsia in Great Britain. Aliment Pharmacol Ther 1996; 10:83-9.

17 Nyren O. Functional dyspepsia-a disorder of the stomach? The Stomach 1990: 385-415.

18 Holtmann G, Goebell G, Talley NJ. Dyspepsia in consulters and non-consulters: prevalence, health-care seeking behaviour and risk factors. Eur J Gastroenterol Hepatol 1994;6:917-24

19 Heikkinen M, Pikkarainen P, Takala J, et al. General practicioners' approach to dyspepsia. Scand J Gastroenterol 1996:31:648-53.

20 Muris JWM, Starmans R, Fijten $\mathrm{GH}$, et al. Abdominal pain in general practice. Fam Pract 1993:10:387-90.

21 Warndorff DK, Knottnerus JA, Huijnen LGJ, et al. How well do general practitioners manage dyspepsia? J R Coll Gen Pract 1989;39:499-502 
22 Bodger K, Daly M, Heatly RV. Prescribing patterns for dyspepsia in primary care: a prospective study of selected general practitioners. Aliment Pharmacol Ther 1996:10:889-5.

23 Anonymous. American Gastroenterology Association medical position paper: evaluation of dyspepsia. Gastroenterology 1997;114:579-81.

24 British Society of Gastroenterology. Dyspepsia Management Guidelines. Guidelines in Gastroenterology 1996;1:1-8.

25 Numans ME, de Wit NJ, Geerdes RHM, et al. NHG-standaard maagklachten, eerste herziening. Huisarts en Wetenschap 1996:39:565-77.

26 Talley NJ, Colin-Jones D, Koch KL, et al. Functional dyspepsia: a classification with guidelines for diagnosis and management. Gastroenterology Intl 1991;4:145-60.

27 Klauser AG, Schindlbeck NE, Muller-Lissner SA. Symptoms in gastro-oesophageal reflux disease. Lancet 1990;335:205-8.

28 Silverstein BD, Pope CE. Role of diagnostic tests in esophageal evaluation. Am J Surg 1980;139:744-8

29 International Agency for Research on Cancer. Cancer incidence in five continents. IARC Monograph on the Evaluation of Carcinogenic Risks to Humans 1987;88: 1-970.

30 Lam SK, Talley NJ. Report of the 1997 Asia pacific consensus conference on the management of Helicobacter pylori infection. J Gastroenterol Hepatol 1997:13:1-12.

31 Heikinnen M, Pikkarainen P, Takala J, et al. Etiology of dyspepsia: four hundred unselected consecutive patients in general practice. Scand J Gastroenterol 1995;30:519-23.

32 Kagevi I, Lofstedt S, Persson LG. Endoscopic findings and diagnoses in unselected dyspeptic paptients at a primary health care center. Scand J Gastroenterol 1989;24:145-50.

33 Hansen JM. Dyspepsia in primary care. Clinical decision making and pharmacotherapy in non-organic dyspepsia. (Thesis, Odense University, Odense, Danmark, 1995.

34 Ayoola EA, al Rashed RS, al Mofleh IA, et al. Diagnostic yield of upper gastrointestinal endoscopy in relation to age and gender: a study of 10112 Saudi patients. Hepato-Gastroenterology 1996;43:409-15.

35 Hungin P. Open access gastroscopy. (Thesis, University of Newcastle upon Tyne, Newcastle upon Tyne, UK, 1995.)

36 Hallissey MT, Allum WH, Jewkes AJ, et al. Early detection of gastric cancer. BM 1990;301:513-15.

37 Fedail SS, Araba BM, Homeida MM, et al. Upper gastrointestinal fibreoptic endoscopy experience in the Sudan. Analysis of 2500 endoscopies. Lancet 1983;ii:897-9.

38 Mansi C, Mela GS, Pasini D, et al. Patterns of dyspepsia in patients with no clinical evidence of organic diseases. Dig Dis Sci 1990;35:1452-8.

39 Holdstock G, Wiseman M, Loehry CA. Open-access endoscopy service for general practitioners. BM 1979;i:457-9.

40 Fjosne U, Kleveland PM, Waldum $\mathrm{H}$, et al. The clinical benefit of routine upper gastrointestinal endoscopy. Scand J Gastroenterol 1986:21:433-40.

41 Capurso $L$, Koch $M$, Dezi $A$, et al. Towards a quantitative diagnosis of dyspepsia: the value of clinical symptoms. Ital J Gastroenterol 1988;20:191-202

42 Stanghellini V, Tosetti C, Paternico A, et al. Risk indicators of delayed gastric emptying of solids in patients with functional dyspepsia. Gastroenterology 1996;110:1036-42.

43 Davenport PM, Morgan AG, Darnborough A, et al. Can preliminary screening of dyspeptic patients allow more effective use of investigational echniques? BM 1985;290:217-20.

44 Nyren O, Adami HO, Gustavsson S, et al. The epigastric distress syndrome-a possible disease entity identified by history and endoscopy in patients with nonulcer dyspepsia. J Clin Gastroenterol 1987:9:303-9.

45 Gear MW, Ormiston MC, Barnes RJ, et al. Endoscopic studies of dyspepsia in the community: an "open-access" service. BMU 1980:280:1135

46 Johannessen T, Petersen $\mathrm{H}$, Kleveland PM, et al. The predicitve value of history in dyspepsia. Scand J Gastroenterol 1990;25:689-97.

47 Bytzer P, Schaffalitzky de Muckadell OB. Prediction of major pathologic conditions in dyspeptic patients referred for endoscopy. A prospective validation study of a scoring system. Scand J Gastroenterol 1992;27:987-92.

48 Talley NJ, Weaver AL, Tesmer DL, et al. Lack of discriminant value of dyspepsia subgroups in patients referred for upper endoscopy Gastroenterology 1993;105:1378-86.

49 Williams B, Luckas $M$, Ellingham JH, et al. Do young patients with dyspepsia need investigation? Lancet 1988;ii:1349-51.

50 Saunders JH, Oliver RJ, Higson DL. Dyspepsia: incidence of a non-ulcer disease in a controlled trial of ranitidine in general practice. $B M$ 1986:292:665-8

51 The Danish Dyspepsia Study Group. Value of the unaided clinical diagnosis in dyspeptic patients in primary care. Am J Gastroenterol 2001;96:1417-21.

52 Adang RP, Ambergen AW, Talmon JL, et al. The discriminative value of patient characteristics and dyspeptic symptoms for upper gastrointestinal endoscopic findings: a study on the clinical presentation of 1,147 patients. Digestion 1996;57:118-34

53 El-Seraq HB, Sonnenberg A. Opposing time trends of peptic ulcer and reflux disease. Gut 1997;43:327-33.

54 Baldi F, GISMAD. Prevalence of reflux esophagitis (RE) in Italy. Gastroenterology 1997:112:A63.

55 Prach AT, MacDonald TA, Hopwood DA, et al. Increasing incidence of Barrett's oesophagus: education, enthusiasm, or epidemiology? Lancet 1997;350:933
56 Blaser MJ. Helicobacter pylori and gastric diseases. BM 1998:316:1507-10

57 Warren JR, Marshall BJ. Unidentified curved bacillus on the gastric epithelium in active chronic gastritis. Lancet 1983;i: 1273-5.

58 Kuipers EJ, Thijs JC, Festen HPM. Helicobacter pylori and peptic ulcer disease. Aliment Pharmacol Ther 1995;9(suppl 2):59-69.

59 Coghlan JG, Gilligan D, Humphries H, et al. Campylobacter pylori and recurrence of duodenal ulcers: a 12 month follow-up study. Lancet 1987;ii: $1109-11$.

60 Lam SK, Ching CK, Lai KC, et al. Does treatment of Helicobacter pylori with antibiotics alone heal duodenal ulcer? A randomised double blind placebo controlled study. Gut 1997;41:43-8.

61 Marshall BJ, Goodwin CS, Warren JR. Prospective double-blind trial of duodenal ulcer relapse after eradiction of Campylobacter pylori. Lancet 1988;ii: 1437-42.

62 Hentschel E, Brandstatter G, Dragosics B, et al. Effect of ranitidine and amoxicilline plus metronidazole on the eradicition of Helicobacter pylori and the recurrence of duodenal ulcer. N Engl J Med 1993:328:308-12.

63 Mantzaris GJ, Hatzis A, Tamvakologos G, et al. Prospective randomised investigator-blind trial of Helicobacter pylori infection treatment in patients with refractory duodenal ulcers. Healing and long term relapse rates. Dig Dis Sci 1993;38: 1132-6.

64 Seppala K, Pikkarainen P, Karvonen AL, et al, group Fgus. The role of Helicobacter pylori eradication in gastric ulcer healing and relapses. Gastroenterology 1992;102:A162.

65 Seppala K, Pikkarainen $\mathrm{P}$, Sipponen $\mathrm{P}$, et al. Cure of peptic gastric ulce associated with eradication of Helicobacter pylori. Finnish Gastric Ulcer Study Group. Gut 1995;36:834-7.

66 Labenz J, Borsch G. Evidence for the essential role of Helicobacter pylori in gastric ulcer disease. Gut 1994;35:19-22.

67 Rauws EA, Tytgat GN. Cure of duodenal ulcer associated with eradication of Helicobacter pylori. Lancet 1990;335:1233-5.

68 Unge P, Gad A, Eriksson K, et al. Amoxicillin added to omeprazole prevents relapse in the treatment of duodenal ulcer patients. Eur $J$ Gastroenterol Hepatol 1993:5:325-31.

69 Forbes GM, Glaser ME, Cullen DJE, et al. Duodenal ulcer treated with Helicobacter pylori eradication: seven year follow-up. Lancet 1994;343:258-60

70 Nomura A, Stemmermann GN, Chyou PH, et al. Helicobacter pylori infection and the risk for duodenal and gastric ulceration. Ann Intern Med 1994; 120:977-81.

71 Sipponen $\mathbf{P}$, Seppala K, Aarynen $M$, et al. Chronic gastritis and gastroduodenal ulcer: a case control study on risk of coexisiting duodenal or gastric ulcer in patients with gastritis. Gut 1989;30:922-9.

72 Sipponen $\mathbf{P}$, Varis K, Fraki O, et al. Cumulative 10 year risk of symptomatic duodenal and gastric ulcer disease in patients with or without chronic gastritis. Scand J Gastroenterol 1990;25:966-73

73 Cullen DJE, Collins J, Christiansen KJ, et al. Long term risk of peptic ulcer disease in people with Helicobacter pylori infection-a community based study. Gastroenterology 1993;104(suppl 2):A60.

74 Jyotheeswaran S, Shah AN, Jin HO, et al. Prevalence of Helicobacter pylori in peptic ulcer patients in greater Rochester, NY: is empirical triple therapy justified? Am J Gastroenterol 1998;93:574-8.

75 Sprung DJ. The natural history of duodenal ulcer disease and how it relates to Helicobacter pylori. Am J Gastroenterol 1997;92:1655

76 Ciociola AA, McSorley DJ, Turner K, et al. Helicobacter pylori infection rates in duodenal ulcer patients in the United States may be lower than previously estimated. Am J Gastroenterol 1999;94:1834-40.

77 Peterson WL, Ciociola AA, Sykes DL, et al, The RBC H pylori study group. Ranitidine bismuth citrate plus clarithromycin is effective for healing duodenal ulcers, eradicating Helicobacter pylori and reducing ulcer recurrence. Aliment Pharmacol Ther 1996;10:251-6

78 Schubert M, De Witt JM, Taylor CA. Prospective evaluation of the prevalence of $\mathrm{H}$ pylori in duodenal abd gastric ulcer: is its role overestimated? Gastroenterology 1999;116:A305

79 Higuchi K, Arakawa T, Fuijwara Y, et al. Is Helicobacter pylori-negative duodenal ulcer masked by the high prevalence of $\mathrm{H}$ pylori infection in the general population? Am J Gastroenterol 1999;94:3083-4

80 EUROGAST study group. An international association between Helicobacter pylori infection and gastric cancer. Lance 1993;341:1359-62.

81 Hansen S, Melby KK, Aase S, et al. Helicobacter pylori infection and risk of cardia cancer and non-cardia gastric cancer. A nested case-control study. Scand J Gastroenterol 1999:34:353-60.

82 Jaskiewicz K, Louwrens HD, Woodroof CW, et al. The association of Campylobacter pylori with mucosal pathological changes in a population at risk for gastric cancer. S Afr Med J 1989;75:417-19.

83 Sipponen P, Kosunen TU, Valle J, et al. Helicobacter pylori infection and chronic gastritis in gastric cancer. J Clin Pathol 1992;45:319-23.

84 Hansson LE, Engstrand L, Nyren O, et al. Helicobacter pylori infection: independent risk indicator of gastric adenocarcinoma. Gastroenterology 1993; 105: 1098-103

85 Kuipers EJ, Gracia-Casanova M, Pena AS, et al. Helicobacter pylori serology in patients with gastric carcinoma. Scand J Gastroenterol 1993:28:433-7.

86 Parsonnet J, Friedman GD, Vandersteen DP, et al. Helicobacter pylori infection and the risk of gastric carcinoma. N Engl J Med 1991;325:1127-31

87 Forman D, Newell DG, Fullerton F, et al. Association between infection with Helicobacter pylori and risk of gastric cancer: evidence from a prospective investigation. BM 1991:302:1302-5.

88 Nomura A, Stemmermann GN, Chyou PH, et al. Helicobacter pylori and gastric carcinoma among Japanese Americans in Hawaii. N Engl J Med 1991;325:1132-6. 
89 Talley NJ, Zinsmeister AR, Weaver A, et al. Gastric adenocarcinoma and Helicobacter pylori infection. I Natl Cancer Inst 1991:83:1734-9. 90 International Agency for Research on Cancer. Schistosomes, liver flukes and Helicobacter pylori. IARC Monograph on the evaluation of carcinogenic risks to humans 1994;61:1-241.

91 Wotherspoon AC, Ortiz-Hidalgo C, Falzon MR, et al. Helicobacter pylori-associated gastritis and primary B-cell gastric lymphoma. Lancet 1991;338: 1175-6.

92 Stolte $\mathbf{M}$. Helicobacter pylori gastritis and gastric MALT-lymphoma. Lancet 1992;339:745-6.

93 Du MQ, Isaacson PG. Recent advances in our understanding of the biology and pathogenesis of gastric mucosa-associated lymphoid tissue (MALT) lymphoma. Forum Genova 1998;8:162-73.

94 Lepore MJ, Smith FB, Bonanno CA. Campylobacter-like organisms in patients with Menetriers disease. Lancet 1988;i:466.

95 Bayerdorffer $E$, Ritter MM, Hatz R, et al. Menetriers disease and Helicobacter pylori disease. N Engl J Med 1993;329:60.

96 Bayerdorffer E, Ritter MM, Hatz R, et al. Healing of protein losing hypertrophic gastropathy by eradication of Helicobacter pylori infection-is Helicobacter pylori a pathogenic factor in Menetriers disease? Gut 1994:35:701-4.

97 Lambert JR. The role of Helicobacter pylori in nonulcer dyspepsia: a debate for. Gastroenterol Clin North Am 1993;22:141-51.

98 Talley NJ. The role of Helicobacter pylori in nonulcer dyspepsia. A debate against. Gastroenterol Clin North Am 1993:22:153-67.

99 Armstrong D. Helicobacter pylori and dyspepsia. Scand J Gastroenterol 1996:215:38-47.

100 Jaakkimainen RL, Boyle E, Tudiver F. Is Helicobacter pylori associated with non-ulcer dyspepsia and will eradication improve symptoms? A meta-analysis. BM 1999;319:1040-4

101 Talley NJ. A critique of therapeutic trials in Helicobacter pylori positive functional dyspepsia. Gastroenterology 1994;106:1174-83.

102 Veldhuyzen van Zanten SJO. A systematic overview (meta-analysis) of outcome measures in Helicobacter pylori gastritis trials and functional dyspepsia. Scand I Gastroenterol 1993:28(suppl 199):40-3.

103 Talley NJ, Vakil N, Ballard ED, et al. Absence of benefit of eradicating Helicobacter pylori in patients with nonulcer dyspepsia. N Engl J Med 1999;341:1106-11

104 Talley NJ, Janssens j, Lauritsen K, et al. $\mathrm{H}$ pylori eradication therapy for non-ulcer dyspepsia. A randomized double-blind placebo controlled longterm trial. Gut 1998:43(suppl 2):A79.

105 McColl K, Murray L, El-Omar E, et al. Symptomatic benefit from eradicting Helicobacter pylori infection in patients with nonulcer dyspepsia. N Engl J Med 1998;339: 1869-74.

106 Blum AL, Talley NJ, O'Morain C, et al. Lack of effect of treating Helicobacter pylori infection in patients with nonulcer dyspepsia. N Engl J Med 1998;339:1875-81.

107 Bruley des Varannes S, Flejou JF, Colin R, et al. Helicobacter pylori eradication in non-ulcer dyspepsia: a randomized, double-blind, placebo-controlled study with a 12-month follow-up. Gastroenterology 2000:118:A468.

108 Froehlich F, Convers JJ, Wietlisbach V, et al. Helicobacter pylori eradication treatment does not benefit patients with non-ulcer dyspepsia. Gastroenterology 2000;118:A469.

109 Koelz HR, Arnold R, Stolte M, et al, FROSCH Study Group. Treatment of Helicobacter pylori $(\mathrm{Hp})$ does not improve symptoms of functional dyspepsia (FD). Gastroenterology 1998;114:A182.

110 Malfertheiner $\mathbf{P}$, Fischbach $W$, Layer $P$, et al. Elan study proves symptomatic benefit of Helicobacter pylori eradication in functional dyspepsia (FD). Gastroenterology 2000;1 18:A440.

111 Miwa H, Hirose M, Kikuchi S, et al. How useful is the detection kit for antibody to Helicobacter pylori in urine (urinalisa) in clinical practice. Am J Gastroenterol 1999;94:3460-3

112 Moayyedi P, Soo S, Deeks J, et al. Systematic review and economic evaluation of Helicobacter pylori eradication treatment for non-ulcer dyspepsia. BN 2000;321:659-64

113 Dhali GK, Garg PK, Sharma MP. Role of anti-Helicobacter pylori treatment in $\mathrm{H}$ pylori-positive and cytoprotective drugs in $\mathrm{H}$ pylori-negative, non-ulcer dyspepsia: results of a randomized, double-blind, controlled trial in Asian Indians. J Gastroenterol Hepatol 1999; 14:523-8

114 Greenberg PD, Cello JP. Lack of effect of treatment for Helicobacter pylori on symptoms of nonulcer dyspepsia. Arch Intern Med 1999:159:2283-8.

115 David J, Lee A, Forbes N, et al. Helicobacter pylori eradication for non-ulcer dyspepsia: a prospective, double-blind, randomized, placebo controlled study. Gastroenterology 1996;110:A91.

116 Passos MCF, Coelho LGV, Gloria ALF, et al. H pylori eradication for functional dyspepsia: a long-term, randomised, prospective double-blind, placebo-controlled study. Gut 1998;43(suppl 2):A81.

117 Sheu BS, Lin CY, Lin XZ, et al. Long-term outcome of triple therapy in Helicobacter pylori-related nonulcer dyspepsia: a prospective controlled assessment. Am J Gastroenterol 1996:91:441-7.

118 Laine L, Schoenfeld P, Fennerty MB. Therapy for Helicobacter pylori in patients with nonulcer dyspepsia. A meta-analysis of randomized, controlled trials. Ann Intern Med 2001;134:361-9.

119 Vicari JJ, Falk GW, Goldblum JR, et al. Helicobacter pylori is not a pathogenic factor in GERD or its complications. Gastroenterology 1997;112:A322.

120 Werdmuller BF, Loffeld RJ. Helicobacter pylori infection has no role in the pathogenesis of reflux esophagitis. Dig Dis Sci 1997;42:103-5.

121 O'Connor HJ. Helicobacter pylori and gastro-oesophageal reflux disease-clinical implications and management. Aliment Pharmacol Ther 1999; 13:117-27.
122 Graham DY, Malaty HM, Evans DG, et al. Epidemiology of Helicobacter pylori in an asymptomatic population in the united states. Effect of age race, and socioeconomic status. Gastroenterology $1991 ; 100: 1495-501$.

123 Banatvala N, Mayo K, Megraud F, et al. The cohort effect and Helicobacter pylori. J Infect Dis 1993;168:219-21.

124 Labenz J, Blum AL, Bayerdorffer E, et al. Curing Helicobacter pylori infection in patients with duodenal ulcer may provoke reflux esophagitis. Gastroenterology 1997;1 12:1442-7.

125 Fallone CA, Barkun AN, Friedman GD, et al. Is Helicobacter pylori eradication associated with gastroesophageal reflux disease? Am J Gastroenterol 2000:95:914-20.

126 Vakil N, Hahn B, McSorley D. Recurrent symptoms and gastro-oesophageal reflux disease in patients with duodenal ulcer treated for Helicobacter pylori infection. Aliment Pharmacol Ther $2000 ; 14: 45-51$.

127 Schwizer W, Thumshirn M, Dent J, et al. Helicobacter pylori and symptomatic relapse of gastro-oesophageal reflux disease: a randomised controlled trial. Lancet 2001;357:1738-42.

128 McColl KEL, Dickson A, El-Nujumi A, et al. Symptomatic benefit 1-3 years after $\mathrm{H}$ pylori eradication in ulcer patients: impact of gastroesophageal reflux disease. Am J Gastroenterol 1999;95:101-5.

129 Kahn K, Greenfield S. Endoscopy in the evaluation of dyspepsia. United States 1984. Health and Public Policy Committee, American College of Physicians, Philadelphia, Pennsylvania. Ann Intern Med 1985; 102:266-9

130 Talley NJ, Silverstein MD, Agreus L, et al. AGA technical review: evaluation of dyspepsia. Gastroenterology 1998:114:582-95.

131 Bytzer P, Hansen JM, Schaffalitzky de Muckadell OB. Empirical $\mathrm{H} 2$-blocker therapy or prompt endoscopy in management of dyspepsia. Lancet 1994;343:811-16.

132 Hungin APS, Thomas PR, Bramble MG, et al. What happens to patients following open access gastroscopy? An outcome study from general practice. BrJ Gen Pract 1994;44:519-21.

133 Jones R. What happens to patients with non-ulcer dyspepsia after endoscopy? Practitioner 1988;232:75-8.

134 Lydeard S, Jones R. Factors affecting the decision to consult with dyspepsia: comparison of conslters and non-consulters. J R Coll Gen Pract 1989;39:495-8

135 Nyren O, Adami HO, Gustavsson S, et al. Social and economic effects of non-ulcer dyspepsia. Scand J Gastroenterol 1985;20/suppl 109):41-5.

136 Brown C, Rees WD. Dyspepsia in general practice. BM 1990:300:829-30.

137 Talley NJ, Meineche-Schmidt V, Pare P, et al. Efficacy of omeprazole in functional dyspepsia: double-blind, randomized, placebo-controlled trials (the Bond and Opera studies). Aliment Pharmacol The 1998; 12:1055-65

138 Lauritsen K, Aalykke C, Havelund T, et al. Effect of omeprazole in functional dyspepsia: a double-blind, randomized, placebo-controlled study. Gastroenterology 1996:110:A702.

139 Blum AL, Arnold R, Koelz HR, et al, FROSCH Study Group. Treatment of functional dyspepsia (FD) with omeprazole and ranitidine. Gastroenterology 1997;1 12:A73

140 Peura DA, Kovacs TO, Metz D, et al. Low-dose lansoprazole: effective for non-ulcer dyspepsia (NUD). Gastroenterology 2000;113:A2418.

141 Richter JE, Long JF. Cisapride for gastroesophageal reflux disease: a placebo-controlled, double-blind study. Am J Gastroenterol 1995:90:423-30.

142 Castell DO, Sigmund C Jr, Patterson D, et al. Cisapride $20 \mathrm{mg}$ bid provides symptomatic relief of heartburn and related symptoms of chronic mild to moderate gastroesophageal reflux disease. CIS-USA-52 Investigator Group. Am J Gastroenterol 1998;93:547-52.

143 Vigneri S, Termini R, Leandro G, et al. A comparison of five maintenance therapies for reflux esophagitis. N Engl J Med 1995:333:1 106-10.

144 Galmiche JP, Fraitag B, Filoche B, et al. Double-blind comparison of cisapride and cimetidine in treatment of reflux esophagitis. Dig Dis Sci cisapride and cimetid

145 Inquen W, Emde C, Weber B, et al. Effects of ranitidine and cisapride on acid reflux and oesophageal motility in patients with reflux oesophagitis: a 24 hour ambulatory combined $\mathrm{pH}$ and manometry study. Gut 1993;34:1025-31.

146 Koelz HR. Treatment of reflux esophagitis with H2-blockers, antacids and prokinetic drugs. An analysis of randomized clinical trials. Scand J Gastroenterol 1989;156:25-36.

147 McCallum RW, Ippoliti AF, Cooney C, et al. A controlled trial of metoclopramide in symptomatic gastroesophageal reflux. N Engl J Med 1977;296:354-7.

148 Toussaint J, Gossuin A, Deruyttere M, et al. Healing and prevention of relapse of reflux oesophagitis by cisapride. Gut 1991;32:1280-5.

149 Baldi F, Bianchi PG, Dobrilla G, et al. Cisapride versus placebo in reflux esophagitis. A multicenter double- blind trial. J Clin Gastroenterol 1988;10:614-18.

150 Arvanitakis C, Nikopoulos A, Theoharidis A, et al. Cisapride and ranitidine in the treatment of gastro-oesophageal reflux disease- $a$ comparative randomized double-blind trial. Aliment Pharmacol The 1993; 7:635-41.

151 Geld of $\mathbf{H}$, Hazelhoff B, Otten MH. Two different dose regimens of cisapride in the treatment of reflux oesophagitis: a double-blind comparison with ranitidine. Aliment Pharmacol Ther 1993;7:409-15.

152 Dakkak M, Jones BP, Scott MG, et al. Comparing the efficacy of cisapride and ranitidine in oesophagitis: a double-blind, parallel group study in general practice. Br J Clin Pract 1994;48:10-14. 
153 Talley NJ. Drug treatment of functional dyspepsia. Scand J Gastroenterol 1991; 182:47-60.

154 Finney JS, Kinnersley N, Hughes $M$, et al. Meta-analysis of antisecretory and gastrokinetic compounds in functional dyspepsia. J Clin Gastroenterol 1998:26:312-20.

155 Dobrilla G, Comberlato M, Steele A, et al. Drug treatment of functional dyspepsia. A meta-analysis of randomized controlled clinical trials. J Clin Gastroenterol 1989;11:169-77.

156 Archimandritis A, Tzivras M, Fertakis A, et al. Cisapride, metoclopramide, and ranitidine in the treatment of severe nonulcer dyspepsia. Clin Ther 1992;14:553-61.

157 Veldhuyzen van Zanten SJ, Cleary C, Talley NJ, et al. Drug treatment of functional dyspepsia: a systematic analysis of trial methodology with recommendations for design of future trials. Am J Gastroenterol 1996;91:660-73

158 Carvalhinhos A, Fidalgo P, Freire A, et al. Cisapride compared with ranitidine in the treatment of functional dyspepsia. Eur J Gastroenterol Hepatol 1995:7:41 1-17.

159 Miazza B, Halter F, Brignoli R. A multicentre comparative trial in functional dyspepsia: cisapride versus cimetidine. Gastroenterology 1993;104:A18

160 Halter F, Miazza B, Brignoli R. Cisapride or cimetidine in the treatmen of functional dyspepsia. Results of a double-blind, randomized, Swiss multicentre study. Scand J Gastroenterol 1994;29:618-23.

161 Simon B, Bergemann W, Bouzo H, et al. Prokinetic drug treatment (cisapride) is as effective as $\mathrm{H} 2$-blocking agent (ranitidine) in the treatment of gastric ulcer. Hepato-Gastroenterology 1991;38/supp 1):41-5.

162 Testoni PA, Bagnolo F, Buizza M, et al. Effectiveness of cisapride in gastric ulcer. Results of a double-blind randomized trial versus ranitidine and versus cisapride plus ranitidine. J Clin Gastroenterol 1993;17:5-9.

163 Stubberod A, Glise H, Hallerback B, et al. The effect of cisapride and ranitidine as monotherapies and in combination in the treatment of uncomplicated gastric ulceration. Scand J Gastroenterol 1995:30:106-10.

164 Kerrigan DD, Taylor ME, Read NW, et al. Acid, motility, and ulcers: a comparison of cisapride with placebo in the prevention of duodenal ulcer relapse. Gut 1993;34:1042-6

165 Food and Drug Administration. FDA warnings for cisapride. Rockville, MD: Department of Public Health and Human Services, 2000: 24:(Jan).

166 Sobala GM, Crabtree JE, Pentith JA, et al. Screening dyspepsia by serology to Helicobacter pylori. Lancet 1991;338:94-6.

167 Mendall MA, Goggin PM, Marrero JM, et al. Role of Helicobacter pylori serology in screening prior to endoscopy. Eur J Gastroenterol Hepatol 992:4.713-17.

168 Mendall MA, Jazrawi RP, Marrero JM, et al. Serology for Helicobacter pylori compared with symptom questionnaires in screening before direct access endoscopy. Gut 1995; 36:330-3

169 Tham TC, McLaughlin N, Hughes DF, et al. Possible role of Helicobacte pylori serology in reducing endoscopy workload. Postgrad Med J 1994:70:809-12.

170 Patel P, Mendall MA, Khulusi S, et al. Salivary antibodies to Helicobacter pylori: screening dyspeptic patients before endoscopy. Lancet 1994;344:511-12.

171 Collins JSA, Bamford KB, Sloan JM, et al. Screening for Helicobacter pylori antibody could reduce endoscopy workload in young dyspeptic patients. Eur J Gastroenterol Hepatol 1992;4:991-3.

172 Vyas SK, Sharpstone D, Treasure J, et al. Pre-endoscopy screening using serodiagnosis of Helicobacter pylori infection. Eur J Gastroenterol Hepatol 1994:6:783-5.

173 Werdmuller BF, der Putten AB, Veenendaal RA, et al. Can screening for lgG antibodies against Helicobacter pylori be used in clinical practice? Omit endoscopy in seropositive or seronegative patients? Dig Dis Sci 1998;43:2296-300

174 Vaira D, Stanghellini V, Menegatti $M$, et al. Prospective screening of dyspeptic patients by Helicobacter pylori serology: a safe policy? The Italian Helicobacter pylori Study Group. Endoscopy 1997:29:595-601

175 Reilly TG, Stone D, Poxon V, et al. H. pylori serology in the investigation of dyspepsia: a general practice based follow-up study. Gut 1996;38(suppl 1):A65

176 Patel P, Khulusi S, Mendall MA, et al. Prospective screening of dyspeptic patients by Helicobacter pylori serology. Lancet 1995;346:1315-18.

177 Asante AA, Mendall M, Patel P, et al. A randomized trial of endoscopy vs no endoscopy in the management of seronegative Helicobacter pylori dyspepsia. Eur J Gastroenterol Hepatol 1998;10:983-9.

178 Fendrick AM, Chernew ME, Hirth RA, et al. Alternative management strategies for patients with suspected peptic ulcer disease. Ann Intern Med 1995;123:260-8.

179 Silverstein MD, Petterson T, Talley NJ. Initial endoscopy or empirical therapy with or without testing for Helicobacter pylori for dyspepsia: a decision analysis. Gastroenterology 1996;110:72-83

180 Sonnenberg A. Cost-benefit analysis of testing for Helicobacter pylori in dyspeptic subjects. Am J Gastroenterol 1996;91:1773-7.

181 Briggs AH, Sculpher M, Logan RP, et al. Cost effectiveness of screening for and eradication of Helicobacter pylori in management of dyspeptic patients under 45 years of age. BM 1996;312:1321-5.

182 Ebell MH, Warbasse L, Brenner C. Evaluation of the dyspeptic patient: cost-utility study. J Fam Pract 1997;44:545-55.

183 Ofman JJ, Etchason J, Fullerton S, et al. Management strategies for Helicobacter pylori-seropositive patients with dyspepsia: clinical and economic consequences. Ann Intern Med 1997;1 26:280-91.

184 Laheij RJ, Severens JL, Jansen JB, et al. Management in general practice of patients with persistent dyspepsia. A decision analysis. J Clin Gastroenterol 1997;25:563-7.
185 Olson AD, Deutsch D. Combined empiric treatment and specific $\mathrm{Hp}$ screening and treatment decrease the cost of evaluating epigastric abdominal pain. Gastroenterology 1998:114:A248.

186 Heaney A, Collins JSA, Watson RGP, et al. A prospective randomised trial of a test- and-treat policy versus endoscopy based management in young Helicobacter pylori positive patients with ulcer-like dyspepsia, referred to a hospital clinic. Gut 1999;45:186-90.

187 Jones R, Tait C, Sladen G, et al. A trial of a test-and-treat strategy for Helicobacter pylori positive dyspeptic patients in general practice. Int $J$ Clin Pract 1999:53:413-16.

188 Lassen AT, Pedersen FM, Bytzer P, et al. Helicobacter pylori test-and-eradicate versus prompt endoscopy for management of dyspeptic patients: a randomised trial. Lancet 2000;356:455-60.

189 Laheij RJ, Severens JL, van de Lisdonk EH, et al. Randomized controlled trial of omeprazole or endoscopy in patients with persistent dyspepsia: a cost-effectiveness analysis. Aliment Pharmacol Ther 1998;12:1249-56.

190 Duggan A, Elliot C, Tolley K, et al. Randomised controlled trial of four dyspepsia management strategies in primary care with 12 months follow-up. Gastroenterology 2000;1 18:A438.

191 Arents NLA, Thiis JC, Zwet van AA, The SENSE Study Working Party. Screening and treating for Helicobacter pylori ("test-and-treat" strategy) in dyspepsia reduces the number of endoscopies and leads to a similar clinical outcome as prompt endoscopy. Gastroenterology 2001;120:A89

192 Klinkenberg-Knol EC, Jansen JM, Festen HP, et al. Double-blind multicentre comparison of omeprazole and ranitidine in the treatment of reflux oesophagitis. Lancet 1987:i:349-51.

193 Hetzel DJ, Dent J, Reed WD, et al. Healing and relapse of severe peptic esophagitis after treatment with omeprazole. Gastroenterology 1988;95:903-12.

194 Hunt RH. The relationship between the control of $\mathrm{pH}$ and healing and symptom relief in gastro-oesophageal reflux disease. Aliment Pharmaco Ther 1995;9(suppl 1):3-7.

195 Lauritsen K, Rune Sj, Bytzer $P$, et al. Effect of omeprazole and cimetidine on duodenal ulcer. A double-blind comparative trial. N Engl J Med 1985:312:958-61.

196 Bardhan KD, Bianchi PG, Bose K, et al. A comparison of two different doses of omeprazole versus ranitidine in treatment of duodenal ulcers. $J$ Clin Gastroenterol 1986;8:408-13

197 Lanza F, Goff J, Scowcroft C, et al. Double-blind comparison of lansoprazole, ranitidine, and placebo in the treatment of acute duodenal ulcer. Lansoprazole Study Group. Am J Gastroenterol 1994;89:1191200.

198 Farup PG, Larsen S, Ulshagen K, et al. Ranitidine for non-ulcer dyspepsia. A clinical study of the symptomatic effect of ranitidine and a classification and characterization of the responders to treatment. Scand J Gastroenterol 1991;26:1209-16.

199 Johannessen T, Kristensen $\mathrm{P}$, Petersen $\mathrm{H}$, et al. The symptomatic effect of 1 -day treatment periods with cimetidine in dyspepsia. Combined results from randomized, controlled, single-subject trials. Scand J Gastroenterol 1991:26:974-80.

200 Johannessen T, Fiosne U, Kleveland PM, et al. Cimetidine responders in non-ulcer dyspepsia. Scand J Gastroenterol 1988;23:327-36.

201 Smith PM, Troughton AH, Gleeson F, et al. Pirenzepine in non-ulce dyspepsia: a double-blind multicentre trial. J Int Med Res 1990;18:16-20.

202 Talley NJ, McNeil D, Hayden A, et al. Randomized, double-blind, placebo-controlled crossover trial of cimetidine and pirenzepine in nonulcer dyspepsia. Gastroenterology 1986:91:149-56.

203 Gad A, Dobrilla G. Campylobacter pylori and non-ulcer dyspepsia. The final results of a double-blind multicentre trial for treatment with pirenzepine in Italy. Scand J Gastroenterol 1989;167:39-43.

204 Rabeneck L, Souchek J, Wristers K, et al. Management of uninvestigated dyspepsia: a randomized, double-blind, placeo-controlled trial of proton pump inhibitor therapy. Gastroenterology 2001;119:A468.

205 Koelz HR, Birchler R, Bretholz A, et al. Healing and relapse of reflux esophagitis during treatment with ranitidine. Gastroenterology 1986;91:1 198-205

206 Graham DY, Colon-Pagan J, Morse RS, et al. Ulcer recurrence following duodenal ulcer healing with omeprazole, ranitidine, or placebo: a double-blind, multicenter, 6-month study. The Omeprazole Duodena Ulcer Study Group. Gastroenterology 1992;102:1289-94.

207 Jones R, Lydeard S. Dyspepsia in the community: a follow-up study. Br J Clin Pract 1992;46:95-7.

208 Talley NJ, Weaver AL, Zinsmeister AR, et al. Onset and disappearance of gastrointestinal symptoms and functional gastrointestinal disorders. Am J Epidemiol 1992;136:165-77.

209 Agreus L, Svardsudd K, Nyren O, et al. Irritable bowel syndrome and dyspepsia in the general population: overlap and lack of stability ove time. Gastroenterology 1995;109:671-80

210 Unge $\mathbf{P}$, Jonsson B, Stalhammar NO. The cost effectiveness of Helicobacter pylori eradication versus maintenance and episodic treatment in duodenal ulcer patients in Sweden. Pharmacoeconomics 1995:8:410-27.

211 Hameeteman W. Columnar-lined (Barrett's) esophagus. (Thesis, University of Amsterdam, Amsterdam, The Netherlands, 1989.)

212 Mann NS, Tsai MF, Nair PK. Barrett's esophagus in patients with symptomatic reflux esophagitis. Am J Gastroenterol 1989;84:1494-6.

213 Winters C Jr, Spurling TJ, Chobanian SJ, et al. Barrett's esophagus. A prevalent, occult complication of gastroesophageal reflux disease. Gastroenterology 1987;92:118-24.

214 van der Burgh A, Dees J, Hop WC, et al. Oesophageal cancer is an uncommon cause of death in patients with Barrett's oesophagus. Gut 1996;39:5-8. 
215 Spechler SJ, Robbins AH, Rubins HB, et al. Adenocarcinoma and Barrett's esophagus. An overrated risk? Gastroenterology 1984:87:927-33.

216 Van der Veen AH, Dees J, Blankensteijn JD, et al. Adenocarcinoma in Barrett's oesophagus: an overrated risk. Gut 1989;30:14-18.

217 Shaheen NJ, Crosby MA, Bozymski EM, et al. Is there publication bia in the reporting of cancer risk in Barrett's esophagus? Gastroenterology 2000;1 19:333-8

218 Rudolph RE, Vaughan TL, Storer BE, et al. Effect of segment length on risk for neoplastic progression in patients with Barrett esophagus. Ann Intern Med 2000;132:612-20.

219 Bytzer P, Christensen PB, Damkier P, et al. Adenocarcinoma of the esophagus and Barrett's esophagus: a population-based study. Am J Gastroenterol 1999;94:86-91.

220220 Smith AM, Maxwell-Armstrong CA, Welch NT, et al. Surveillance for Barrett's oesophagus in the UK. Br J Surg 1999;86:276-80.

221 van Sandick JW, Bartelsman JF, van Lanschot JJ, et al. Surveillance of Barrett's oesophagus: physicians' practices and review of current guidelines. Eur J Gastroenterol Hepatol 2000;12:1 11-17.

222 Richter JE, Falk GW. Barrett's esophagus and adenocarcinoma. The need for a consensus conference. J Clin Gastroenterol 1996;23:88-90.

223 Spechler SJ, Lee E, Ahnen D, et al. Long-term outcome of medical and surgical therapies for gastroesophageal reflux disease: follow-up of a randomized controlled trial. JAMA 2001;285:2331-8.

224 Johansson KE, Tibbling L. Maintenance treatment with ranitidine compared with fundoplication in gastro-oesophageal reflux disease. Scand J Gastroenterol 1986;21:779-88.

225 Negre JB, Markkula HT, Keyrilainen O, et al. Nissen fundoplication. Results at 10 year follow-up. Am J Surg 1983;146:635-8.

226 Spechler SJ. Comparison of medical and surgical therapy for complicated gastroesophageal reflux disease in veterans. The Department of Veterans Affairs Gastroesophageal Reflux Disease Study Group. N Engl J Med 1992;326:786-92

227 Griffin SM, Raimes SA. Proton pump inhibitors may mask early gastric cancer. Dyspeptic patients over 45 should undergo endoscopy before these drugs are started. BMU 1998;317:1606-7.

228 Breslin NP, Thomson ABR, Bailey RJ, et al. Gastric cancer and other endoscopic diagnoses in patients with benign dysplasia. Gut 2000;46:93-97.

229 Christie J, Shepherd NA, Codling BW, et al. Gastric cancer below the age of 55: implications for screening patients with uncomplicated dyspepsia. Gut 1997:41:513-17

230 Gillen D, McColl KE. Does concern about missing malignancy justify endoscopy in uncomplicated dyspepsia in patients aged less than 55 ? Am J Gastroenterol 1999.94:75-9.

231 Leodolter A, Dominguez-Munoz JE, von Arnim U, et al. Validity of a modified 13C-urea breath test for pre-and posttreatment diagnosis of Helicobacter pylori infection in the routine clinical setting. Am J Gastroentero 1999;94:2100-4

232 Savarino V, Mela GS, Zentilin P, et al. Comparison of isotope ratio mass spectrometry and nondispersive isotope-selective infrared spectroscopy for 13C-urea breath test. Am J Gastroenterol 1999:94:1203-8.

233 Vaira D, Malfertheiner P, Megraud F, et al. Diagnosis of Helicobacter pylori infection with a new non-invasive antigen-based assay. Lancet 1999:354:30-3.

234 Vaira D, Malfertheiner P, Megraud F, et al. Noninvasive antigen-based assay for assessing Helicobacter pylori eradication: a European multicenter study. Am J Gastroenterol 2000;95:925-9.

235 Arents NLA, van Zwet AA, Thiis JC, et al. The accuracy of the Helicobacter pylori stool antigen test in diagnosing $\mathrm{H}$ pylori in treated and untreated patients. Eur J Gastroenterol Hepatol 2001 1 13:383-6.

236 NIH Consensus Conference. Helicobacter pylori in peptic ulcer disease. JAMA 1994;272:65-9.

237 van der Wouden EJ, Thijs JC, van Zwet AA, et al. Six year follow-up after successful triple therapy for Helicobacter pylori infection in patients with peptic ulcer disease. Gut 1998;43(suppl 2):A100.

238 Bell GD, Powell KU, Burridge SM, et al. Reinfection or recrudescence after apparently successful eradication of Helicobacter pylori infection: implications for treatment of patients with duodenal ulcer disease. $Q j$ implications for treatment $1993: 86: 375-82$

239 Abu-Mahfouz MZ, Prasad VM, Santogade P, et al. Helicobacter pylori recurrence after successful eradication: 5-year follow-up in the United States. Am J Gastroenterol 1997;92:2025-8.
240 Borody TJ, Andrews P, Mancuso N, et al. Helicobacter pylori reinfection rate, in patients with cured duodenal ulcer. Am J Gastroenterol 1994:89:529-32.

241 Borody T, Andrews P, Mancuso N, et al. Helicobacter pylori reinfection 4 years post- eradication. Lancet 1992;339:1295.

242 van der Hulst RW, Rauws EA, Koycu B, et al. Prevention of ulcer recurrence after eradication of Helicobacter pylori: a prospective long-term follow-up study. Gastroenterology 1997:113:1082-6.

243 Uemura N, Mukai T, Okamoto S, et al. Helicobacter pylori eradication inhibits the growth of intestinal type of gastric cancer in initial stage. Gastroenterology 1996;110:A282.

244 Kuipers EJ, Lundell L, Klinkenberg-Knol EC, et al. Atrophic gastritis and Helicobacter pylori infection in patients with reflux esophagitis treated with omeprazole or fundoplication. N Engl J Med 1996;334:1018-22.

245 Lamberts R, Creutzfeldt W, Struber HG, et al. Long-term omeprazole therapy in peptic ulcer disease: gastrin, endocrine cell growth, and gastritis. Gastroenterology 1993;104:1356-70.

246 Mowat C, Williams C, Gillen D, et al. Omeprazole, Helicobacter pylori status, and alterations in the intragastric milieu facilitating bacterial N-nitrosation. Gastroenterology 2000;1 19:339-47.

247 Uemura N, Okamoto S, Yamamoto S, et al. Changes in Helicobacter pylori-induced gastritis in the antrum and corpus during long-term acid-suppressive treatment in japan. Aliment Pharmacol Ther 2000;14:1345-52

248 Genta RM. Atrophy, acid suppression and Helicobacter pylori infection: a tale of two studies. Eur J Gastroenterol Hepatol 1999;11(suppl 2):S29-S33.

249 Bell GD, Powell K, Burridge SM, et al. Experience with "triple" anti-Helicobacter pylori eradication therapy: side effects and the importance of testing the pre-treatment bacterial isolate for metronidazole resistance. Aliment Pharmacol Ther 1992;6:427-35

250 Thijs JC, van Zwet AA, Oey HB. Efficacy and side effects of a triple drug regimen for the eradication of Helicobacter pylori. Scand J Gastroenterol 1993;28:934-8.

251 Thijs JC, van Zwet AA, Moolenaar W, et al. Triple therapy vs. amoxicillin plus omeprazole for treatment of Helicobacter pylori infection: a multicenter, prospective, randomized, controlled study of efficacy and side effects. Am J Gastroenterol 1996;91:93-7.

252 Marshall BJ, Hoffman SR, McCallum RW. Incidence of side effects during bismuth subsalicylate and antibiotic therapy for $\mathrm{H}$ pylori (HP) Gastroenterology 1992;100:A117.

253 de Boer WA, Tytgat GN. The best therapy for Helicobacter pylori infection: should efficacy or side-effect profile determine our choice? Scand J Gastroenterol 1995;30:401-7.

254 Houben MH, van de Beek D, Hensen EF, et al. Helicobacter pylori eradication therapy in The Netherlands. Scand J Gastroenterol 1999;34(suppl 230): 17-22.

255 van der Wouden EJ, Thiis JC, van Zwet AA, et al. The influence of in vitro nitroimidazole resistance on the efficacy of nitromidazole containing anti-Helicobacter pylori regimens: a meta-analysis. Am J Gastroenterol 1999:94:1751-9.

256 Laheij RJ, Rossum LG, Jansen JB, et al. Evaluation of treatment regimens to cure Helicobacter pylori infection - a meta-analysis. Aliment Pharmacol Ther 1999:13:857-64.

257 Schmid $\mathbf{C H}$, Whiting G, Cory D, et al. Omeprazole plus antibiotics in the eradication of Helicobacter pylori infection: a meta-regression analysis of randomized, controlled trials. Am J Ther 1999;6:25-36.

258 Unge P, Berstad A. Pooled analysis of anti-Helicobacter pylori treatment regimens. Scand J Gastroenterol 1996;220:27-40.

259 van der Wouden EJ, van Zwet AA, Vosmaer GD, et al. Rapid increase in the prevalence of metronidazole-resistant Helicobacter pylori in the Netherlands. Emerg Infect Dis 1997:3:385-9.

260 Megraud F. Epidemiology and mechanism of antibiotic resistance in Helicobacter pylori. Gastroenterology 1998;115:1278-82.

261 de Boer WA. How to achieve a near $100 \%$ cure rate for $\mathrm{H}$ pylor infection in peptic ulcer patients. A personal viewpoint. J Clin Gastroenterol 1996;22:313-16.

262 Schutze K, Hentschel E, Dragosics B, et al. Helicobacter pylori reinfection with identical organisms: transmission by the patients' spouses. Gut 1995;36:831-3.

263 Graham DY. The only good Helicobacter pylori is a dead Helicobacter pylori. Lancet 1997;350:70-1 